\title{
Comparison between Palpation and Superficial Marking Techniques in Determining Infraorbital Foramen in Chinese Women
}

\author{
Lindawati ${ }^{1}$, Arifin Soenggono ${ }^{2}$, Hardi Siswo $\mathrm{S}^{3}$ \\ ${ }^{1}$ Faculty of Medicine, Universitas Padjadjaran, ${ }^{2}$ Department of Anatomy, Faculty of Medicine, \\ Universitas Padjadjaran, ${ }^{3}$ Department of Surgery, Faculty of Medicine, Universitas Padjadjaran/ \\ Dr. Hasan Sadikin General Hospital Bandung
}

\begin{abstract}
Background: Difficulties in determining infraorbital foramen were often found in anesthesia procedures, reconstruction surgery, acupuncture, and botox insertion. The most common technique used is palpation technique. However, there are some disadvantages in this technique.The aim of this study was to establish a new superficial marking technique to determine the position of infraorbital foramen by making a horizontal imaginary line from the top part of nose wings.

Methods: This study was an analytical cross-sectional study conducted at the Faculty of Medicine, Universitas Padjadjaran in Jatinangor-Sumedang during the period of April to November 2012. A total of thirty Chinese female students were assessed to measure the mean distance between the inferior orbital margin to the infra orbital foramen and inferior orbital margin to horizontal imaginary line from the top part of nose wings. The differences were then checked using paired t-test.

Results: There was a significance difference between the mean distance of the inferior orbital margin to the infra orbital foramen and the inferior orbital margin to the horizontal imaginary line from the top part of the nose wings on the right and left face of Chinese women with $\mathrm{p}<0.05(\mathrm{p}=0.000)$.

Conclusion: Infra orbital foramen cannot be determined by using superficial marking technique in Chinese women.
\end{abstract}

Keywords: Infra orbital foramen, palpation technique, superfacial marking technique

\section{Introduction}

Infraorbital foramen is an opening where the infraorbital neurovascular pass through. ${ }^{1}$ Infraorbital foramen is located on maxillary bone1, 4-13 $\mathrm{mm}$ from the inferior orbital margin ${ }^{2-5}$, parallel to the top part of nose wings $^{6-8}$, and located $2 \mathrm{~cm}$ from the top part of nose wings. ${ }^{6,7}$ Knowledge about the right location of infraorbital foramen provides data in anesthesia procedures for reconstructive surgery in maxillofacial trauma ${ }^{9,10}$; rhinoplasty surgery and withdrawing teeth surgery ${ }^{7}$; trigeminal neuralgia and facial palsy treatment in medical acupuncture11; and botox insertion in esthetic field. ${ }^{12}$

In determining the anatomical landmark of infraorbital foramen in human, the palpation technique is used. ${ }^{7}$ Palpation starts from inferior orbital margin down to infraorbital foramen, which pass through the imaginary line from the middle of pupils vertically. ${ }^{7}$
Palpation technique has some disadvantages such as difficulty in determining the location of the foramen if the patient has a thick skin.13 Palpation technique also gives an uncomfortable feelings for the patient, caused by the pressure over the infraorbital nerve. Infraorbital nerve is located superficially on the surface of the facial skin, because there is no deep fascial layer on the facial skin surrounding the infraorbital foramen. ${ }^{14}$ This study was undertaken to establish a new superficial marking technique to determine infraorbital foramen by making a horizontal imaginary line from the top part of nose wings. Mean difference between the distance of inferior orbital margin to infraorbital foramen and inferior orbital margin to horizontal imaginary line from the top part of nose wings needs to be known.

Chinese women were chosen as the sample for the homogeneity of the subjects Studies on Chinese people are still low, so the anthropometry data are limited. The amount

Correspondence: Lindawati, Faculty of Medicine, Universitas Padjadjaran, Jalan Raya Bandung-Sumedang Km.21, Jatinangor, Sumedang, Indonesia, Phone: +62 81394694098 Email : chenciayi@rocketmail.com 
of Chinese people in Indonesia are rising (4$5 \%$ from the total citizens of Indonesia), and two-thirds of it are women. ${ }^{15}$ Chinese is one of the ethnic groups in Indonesia which is still pure without any mixing with other ethnic groups, at least two generation. ${ }^{16}$

\section{Methods}

This research was conducted at the Faculty of Medicine, Universitas Padjadjaran in Jatinangor-Sumedang during the period of April to November 2012. Thirty Chinese female students from Faculty of Medicine, Universitas Padjadjaran batch 2009-2012 were taken as the subjects by using simple random sampling technique. The inclusion criteria were Chinese subject with two generation before being pure Chinese; aged 18 years old or older; Body Mass Index (BMI) is 25 or under; and the subject should be never done any reconstruction surgery or do not have any damage and injury to the facial bones. The exclusion criteria were the subjects who refused to become a sample with any reason. Every sample was given an informed consent form as an agreement letter to become the subject of this research. This research has been approved by the Health Research Ethics Committee.

Both sides of each face of the subjects were measured based on the mean distance of $X$ (the distance of inferior orbital margin to infraorbital foramen) and Y (the distance of inferior orbital margin to the top part of nose wings). The subjects must sit upright, the head must be straight, and the viewpoint of the eyes must be straight-forward. A vertical imaginary line from the middle of the pupils was made by using a plumb line.

In palpation technique (Technique $A$ ), the location of the inferior orbital margin was palpated which was on the vertical imaginary line, then marked by giving a dot. The infraorbital foramen was palpated down from the inferior orbital margin which was on the vertical imaginary line, then marked by giving a dot. The distance of inferior orbital margin to infraorbital foramen was measured by using vernier calipers, capable of measuring to the nearest $0.01 \mathrm{~mm}$ (Figure 1).

In superfacial marking technique (Technique B), a horizontal imaginary line from the top part of nose wings was made by using a ruler. This horizontal imaginary line must be intersected with the vertical imaginary line from the middle of the pupils. The intersection point of these two imaginary lines was marked by giving a dot using a pen. The distance of the inferior orbital margin to the intersection point was measured by using vernier calipers (Figure 2 ).

All of the measurements of A and B were done bilaterally on the right and left face of the samples and repeated three times. The mean distance was calculated and analyzed by using paired T-test.

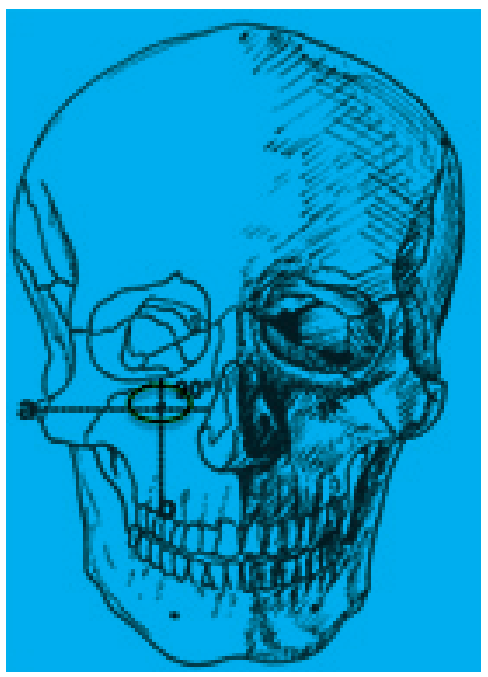

Figure 1 The Association of Vertical Imaginary Line That Pass Through The Middle of Infraorbital Foramen and Inferior Orbital Margin With Horizontal Imaginary Line That Pass Through The Infraorbital Foramen and The Opening of Piriformis ${ }^{3}$ 


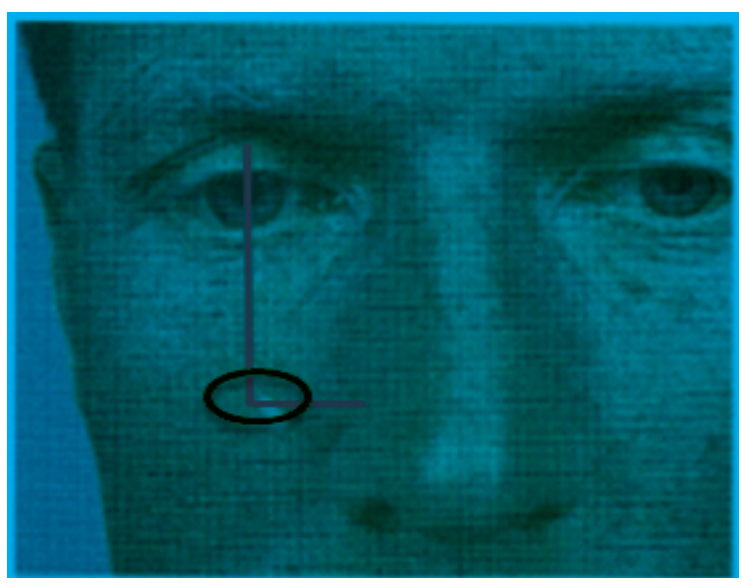

Figure 2 The Association Between Inferior Orbital Margin, Infraorbital Foramen, Vertical Imaginary Line From The Middle of The Pupils, and Horizontal Imaginary Line From The Top Part of Nose Wings in the Human's Face ${ }^{8}$

\section{Results}

The mean distance of inferior orbital margin to infraorbital foramen on the right face of the Chinesewomen(TechniqueA) was $14.48 \pm 1.787$ $\mathrm{mm}$ and on the left face was $14.48 \pm 1.829 \mathrm{~mm}$. The mean distance of inferior orbital margin to the horizontal imaginary line from the top part of nose wingson the right face of the Chinese women (Technique B) was $14.98 \pm 1.687 \mathrm{~mm}$ and on the left face was $15.00 \pm 1.751 \mathrm{~mm}$.

There is a significance difference between $A$ and $B$ on the right and left face of Chinese women (Table 1).

\section{Discussions}

The superficial marking technique by making a horizontal imaginary line from the top part of nose wings yield a significant difference with the palpation technique. Superficial marking technique cannot be used as an alternative for the palpation technique. Every person has genetic, nutrition intake, hormone, and also physical activity variations.
Growth and development of the bone and cartilage of the face are influenced by genetic, nutrition, hormone, and physical variation. ${ }^{17}$ Genetic plays an important role in influencing the shape, the velocity of the growth and development, and any physical changing of the bone and the cartilage. ${ }^{17}$ Besides genetic, nutrition also plays an important role. A big amount of calcium and phosphorus and a small amount of magnesium, fluoride, and manganese are needed in the growing of the bone by helping the formation of the bone, strengthening the bone, and activating the enzymes needed to synthesize the extracellular matrix of the bone and cartilage. ${ }^{17}$ Vitamin A, $\mathrm{C}, \mathrm{D}, \mathrm{K}$, and B12 are needed to stimulate the activity of osteoblast to synthetize the collagen as the main protein of the bone, to help the absorption of the calcium from the food, and to synthesize the protein of the bone. ${ }^{17}$

Some hormones are needed for the growth and development of the bone and cartilage. They are human growth hormone (hGH), insulin like growth factor (IGFs), insulin, thyroid hormone, estrogen, and progesteron. These hormones are needed

Table 1 The Mean Distance of Inferior Orbital Margin to Infraorbital Foramen and Horizontal Imaginary Line

\begin{tabular}{ccccc}
\hline & \multicolumn{2}{c}{ Technique A } & \multicolumn{2}{c}{ Technique B } \\
\cline { 2 - 5 } & Left $(\mathbf{m m})$ & Right $(\mathbf{m m})$ & Left $(\mathbf{m m})$ & Right $(\mathbf{m m})$ \\
\hline Mean (SD) & $14.48(1.829)$ & $14.48(1.787)$ & $14.98(1.687)$ & $15.00(1.751)$ \\
$\mathrm{p}$ & 0.000 & 0.000 & 0.000 & 0.000 \\
\hline
\end{tabular}


to stimulate the growth of the bone and cartilage, to stimulate osteoblast, to increase the bone protein synthesis, to stimulate fast growing in adolescent, to stop the growth of epiphyseal plateat the age of $\geq 18$ years old, and to stimulate the bone deposition by osteoblast. ${ }^{17}$ Parathyroid hormone is needed for bone resorption byosteoclastand vitamin D formation. ${ }^{17}$ Calcitonin is needed to hamper the bone resorption by osteoclast. ${ }^{17}$ The last factor that influences the growth and development of the bone and cartilage is physical activity or exercise ${ }^{17}$ Exercise or physical activity will stimulate the osteoblast activity. ${ }^{17}$

Every person has different amounts of neurovascular which supply the bone and cartilage; different osteoblastic, osteoclastic, and chondroblastic activity; also different interstitial and a positional growth of the bone and cartilage. ${ }^{17}$ These will make a big variation from the shape of the face and nose, the length and width of the head, and the distance of interchantus of the eyes of every sample. Nose wings are made from the flexible hyaline cartilage, so the shape of the nose of every sample will have a big variation. This explains about the reason of the intersection point between the horizontal imaginary line from the top part of nose wings and the vertical imaginary line from the middle of the pupils, will not fall accurately on the infraorbital foramen.

It can be concluded that infraorbital foramen cannot be determined by using superficial marking technique in Chinese women.

The limitation of this study was the various factors that can influence of the anatomy of face was not considered in this study. Furthermore, the shape of the nose and face, the length and width of the head, and the distance of the interchantus of the eyes from every sample are needed to be equated. Further studies on other gender and ethnic groups also need to be undertaken. Further studies on other alternative to determine the anatomical landmark of infraorbital foramen need to be explored.

\section{References}

1. Moore KL, Dalley AF, Agur AMR. Clinically oriented anatomy. 6th edition. Philadelphia: Lippincott Williams \& Wilkins; 2009.

2. Apinhasmit W, Chompoopong S, Methathrathip D, Sansuk R,
Phetphunphiphat W. Supraorbital notch/ foramen, infraorbital foramen and mental foramen in thais: anthropometric measurements and surgical relevance. J Med Assoc Thai. 2006;89(5):675-82.

3. Elias MG, Silva RB, Pimentel ML, Rivello VTS, Babinski MA. Morphometric analysis of the infraorbital foramen and acessories foraminas in brazillian skulls. Int J Morphol. 2004;22(4):273-8.

4. Ilayperuma I, Nanayakkara G, Palahepitiya $\mathrm{N}$. Morphometric analysis of the infraorbital foramen in adult sri lankan skulls. Int J Morphol.2010;28(3):777-82.

5. Singh R. Morphometric analysis of infraorbital foramen in indian dry skulls. Anat Cell Biol. 2011;44(1):79-83.

6. Salin MB, Smith BM. Diagnosis and treatment of midface fractures. In: Foncesa RJ, Walker RV, Betts NJ, Barber HD, Powers MP, editors. Oral and maxillofacial trauma. St. Louis, Missouri: Elsevier Saunders; 2005. p. 650-82.

7. Gaertner E, Nasser BA, Choquet O, Drizenko A, Macaire P, Martin R, et al. Regional anesthesia: peripheral nerve blockade in adults. Paris: Arnette Blackwell; 2004.

8. Lian YL, Ogal HP, Stor W, editors. The seirin pictorial atlas of acupuncture. Cologne: Konemann Verlagsgesellschaft mbH; 2000.

9. Moedder U, Cohnen $\mathrm{M}$, Andersen $\mathrm{K}$, Engelbrecht V, Fritz B. Head and neck imaging. New York: Thieme; 2007.

10. Curran J. Anesthesia for maxillofacial trauma. In: Shaw I, Kumar C, Dodds C, editors. Oxford textbook of anaesthesia for oral and maxillofacial surgery. Oxford: Oxford University Press; 2010. p. 186.

11. Quirico PE, Pedrali T. Teaching atlas of acupuncture: channels and points. New York: Thieme; 2007.

12. Donath AS. Facial rejuvenation : a chronology of procedures. In: Farage MA, Miller KW, Maibach HI, editors. Textbook of aging skin. Berlin: Springer; 2010. p. 1175-6.

13. Hughes CG, Weavind L, Pandharipande PP. Sedation, paralysis, and pain management of the critically ill obese patients. In: Solh $\mathrm{AE}$, editor. Critical care management of the obese patient. Oxford: Wiley - Blackwell 2012. p. 49.

14. Snell RS. Clinical anatomy by regions 8th edition. Philadelphia: Lippincott Williams and Wilkins; 2008. 
Lindawati, Arifin Soenggono, Hardi Siswo S: Comparison between Palpation and Superficial Marking Techniques 9 in Determining Infraorbital Foramen in Chinese Women

15. Maryati K, Suryawati J. Sosiologi untuk SMA dan MA kelas XI. Jakarta: Esis; 2006.

16. Waluya B. Sosiologi: menyelami fenomena sosial di masyarakat. Bandung: PT Setia Purna Inves; 2007.
17. Tortora GJ, Derrickson BH. Principles of anatomy and physiology : organization, support, and movement, and control systems of the human body 12 th edition. New York: John Wiley \& Sons; 2009. 